\title{
Use of Modern methods for Evaluation of Motor Performance
}

\section{Bojan Bjelica ${ }^{a}{ }^{*}$ (D), Borislav Cicović ${ }^{a}$, Ljubica Milanović ${ }^{a}$, Milan Zelenović ${ }^{a}$ (D),}

\section{Danijel Božić a (iD}

a Faculty of Physical Education and sport, University of East Sarajevo, Pale, 71420, Bosnia and Herzegovina

*Corresponding author Ph: +387 65057 961; Email: vipbjelica@gmail.com

DOI: https://doi.org/10.34256/ijpefs2112

Received: 24-12-2020, Revised: 23-01-2021; Accepted: 24-01-2021; Published: 26-01-2021

Abstract: The development of instruments and the use of the same is expanding from year to year. The paper aims to determine the usefulness of Myotesta (MT), Optojump (OJ), Globe Ergo System (GES) as modern methods for assessing motor performance. The research included nine original scientific papers. All wsorks satisfied the problem and could answer the set goal. The selection of works from 2009. to 2014. was taken as a method. There are specific differences when comparing the results for each of the instruments. Myotest has stood out as the smallest instrument and is easily portable and therefore effective to use. The assessment of explosive power is easy to perform, and the results it gives are reliable.

Keywords: Myotest, Globus Ergo, Opto-jump, Vertical jump, Reliability, Validity.

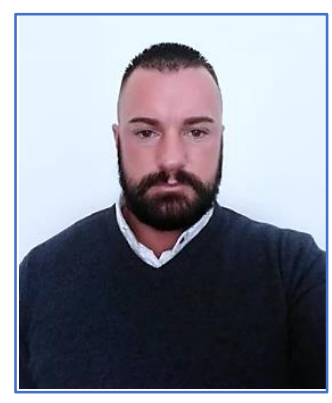

Mr. Bojan Bjelica was born on 14th September 1987 in Sarajevo, municipality of Centar. He completed his Bachelors and Masters in Physical Education. Since April 2014, he is working as an assistant on the Faculty of Sport and physical education in East Sarajevo on the subject SPORTS RECREATION. Besides, from 2017 he is also working at the Faculty of Economy in Pale as an assistant on the subjects: ECONOMY OF SPORT, ECONOMY OF SPORT RECREATION. Currently, he is doing his doctoral studies in Niš, Republic of Serbia. Since 2016 he is an active member of the ANTHROPOLOGICAL SOCIETY OF SERBIA. Besides his research, he is also serving as an Editorial board member for many international journals.

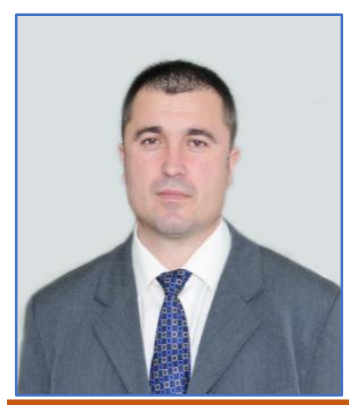

Dr. BORISLAV CICOVIĆ born on $22^{\text {nd }}$ August 1972 in Zemun, Republic of Serbia. He graduated in 2004 from the Faculty of Physical Education in East Sarajevo. Graduation thesis entitled: "Methodical procedure of learning the side technique of throwing Uči mata". In 2007, he defended his master's thesis at the Faculty of Physical Education, University of East Sarajevo, entitled: "The influence of morphological characteristics and motor skills on the situational motor abilities of judokas." In 2009, he defended his doctoral dissertation at the Faculty of Physical Education and Sports, University of East Sarajevo, entitled: "Changes in motor, situational motor and functional abilities in selected judokas under the influence of training activities." He started working at the Faculty of Physical Education and Sports, University of East Sarajevo in 2006 as an assistant in the subject of Martial Arts. Currently he is the Associate Professor cum dean of the faculty.

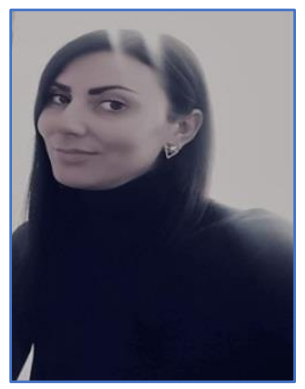

Ms. Ljubica Milanović, M.Sc., was born on September 12, 1985. in Vlasenica. After graduating from high school, in 2004, she enrolled at the Faculty of Physical Education at the University of East Sarajevo, graduating in 2008 as an award-winning student by the faculty's dean. Along with this she also acquired the title of the graduate pedagogue. She enrolled in postgraduate studies immediately after completing her undergraduate studies and received the Master of Science in Physical Culture title in 2010. Currently she 
is doing her $\mathrm{PhD}$ at the Faculty of Sports and Physical Education in Nis. Since 2020, she has been working at the Faculty of Physical Education and Sports of the University of East Sarajevo as a senior assistant.

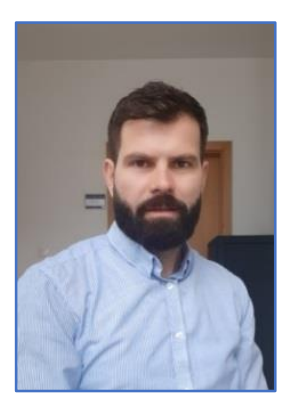

Mr. Milan Zelenović was born in 1987 in Sarajevo. He graduated and obtained his master's degree at the Faculty of Physical Education and Sports, University of East SarajevoBosnia and Herzegovina, where he is also employed as an assistant professor for the narrow scientific field of sports and rehabilitation science - Kinesiology of collective sports. He is currently working on his doctoral thesis at the Faculty of Sports and Physical Education, University of Nis, Serbia. He worked as a teacher and professor of physical education in several primary and secondary schools and as a coach in basketball clubs.

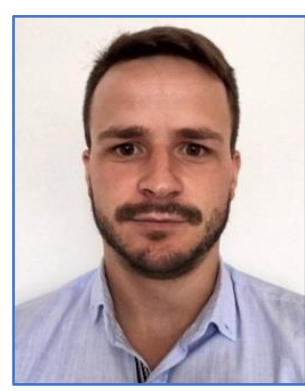

Mr. Danijel Božić was born on $31^{\text {st }}$ July 1991 in Gradačac. After graduating from high school, he enrolled in the first year of study at the Faculty of Physical Education and Sports, University of East Sarajevo, majoring in physical education, where he completed basic and master studies in 2016. He is enrolled in doctoral academic studies in 2019 at the Faculty of Sports and Physical Education in Nis. Since 2018, he has been working at the Faculty of Physical Education and Sports of the University of East Sarajevo as an assistant for the narrower scientific field of Sports and Rehabilitation Science / Department of Individual Sports

\section{Introduction}

In the last fifteen years, the instrumentation has been increasingly used, both in the laboratory and in the field, for various measurements in both recreational and professional sports [1-3]. The quality of measurement through an instrument or device, refers to the reliability and validity, so before using in practice, you should first research and test the instrument [4-6]. From a biomechanical aspect, explosive power is required in athletic disciplines such as long jump, high jump and throwing discipline [7]. The use of these types of instruments requires the socalled. plate or platform, which is not always a practical and cost-effective option, as it is generally related to laboratory research $[4,8]$.The contact plate is one of the most present and practical ways of measuring the height of the vertical jump and is based on the method of breaking the continuous circuit built into the substrate. The board detects the presence, or absence, of the subject from the platform (ie the center of gravity) and based on the time spent in the jump, the software package displays the other parameters of the jump.

Myotest (MT), uses three-dimensional accelerometer technology. Thanks to the use of accelerometers, this device is easy to handle in different research conditions and is not massive [9, 10]. The MT system allows the calculation of the jump height using an accelerometer mounted on the hips and thus determines the change in the movement of the sensor (jump height). The jump height can also be estimated by measuring the flight time with the help of the contact platform Globus Ergo System (GES) [11]. There have been many studies assessing the explosive power of the lower extremities $[7,12,13]$. GES is a portable instrument. Thanks to the special modular structure, it can be easily used starting from the installation of the device. The device is used in all top institutes around the world. The price of the device is quite high, but so are the possibilities.

Optojump (OJ) is an optical measurement system that can be used in motion tests that require time measurement. The use is simple, it can be used to measure vertical jump height and many more possibilities [14, 15]. According to the authors, jump estimation platforms give reliable and accurate results [16-18].

The aim of this paper is to determine the costeffectiveness of use (Myotesta (MT), Optojump (OJ) Globus Ergo System (GES) and the accuracy of the results of these devices.

\section{Method}

Research data for the purposes of this paper were collected through electronic databases PubMed, Scholar Google, DOAJ. The search of works was done in the period from 2009 to 2014. The following keywords were used in the database research: Myotest, Globus Ergo, Opto-jump, vertical jump, reliability, validity. The found research titles, abstracts and full texts were then read and analyzed. In order for the research to be accepted for the final analysis, it had to meet two criteria: the first criterion refers to the review of the selected instruments, the second criterion is the implementation of the analysis of works in the selected period. Research that met the set 
criteria were then analyzed and presented on the basis of the following parameters: reference (first letter of the author and year and year of publication of the research, sample of respondents.

\section{Research results}

The procedure for collecting, analyzing and eliminating the found works is given in Figure 1. Based on the key words, 302 works were identified. The number of studies that were immediately excluded on the basis of titles, duplicate papers, as well as papers that were excluded on the basis of the period when they were published (older than 2009) is 265, while 31 papers were included in further analysis. Further analysis of 37 papers excluded 28 papers based on several criteria: abstract, because it was a systematic review research, as well as the absence of a control group in the research. The remaining nine works met the set criteria, namely: works published in the period from 2009 to 2014, are shown in Table 1.

\section{Discussion}

The discussion included nine original papers and about 400 respondents. The aim of this paper is to determine the use of Myotest (MT), Optojump (OJ) Globus Ergo System (GES) as modern methods for assessing motor performance. The first row of the table contains data from a survey conducted on a sample of 73 respondents, 40 female and 33 male respondents. The respondents were students. Three types of jumps were used as a protocol and analyzed on the basis of two instrumentation systems Optojump and IR-mat Ergotest. Both systems are started by a timer with great precision. Flight time using IR-mat Ergotest was longer. The differences between these two systems are insignificant, but they are significant.
In conclusion, both systems can be used alternately.

The second row of the table contains data from a survey conducted on a sample of 10 students. The aim of the study was to determine the use of Myotest and its functionality in performing jumps. Subjects performed five vertical jumps on initial and final testing. Statistical processing indicates high reliability of the instrument. The Myotest is reliable and easy to operate. Its diversity of protocols can be useful to assess the explosive strength of coaches, athletes, physicians, and patients, and to plan and implement a training and recovery program.

The third row of the table contains data from a survey conducted on a sample of 79 male and female students. The aim of the research was to determine which instrument is more valid. These are: Myotest; Just Jump; Vertec. The evaluation of the vertical jump was done simultaneously with all three devices. Certain irregularities and errors were noticed with the Vertec system, while Myotest gave the best results for both students. In order for the results to be more valid when using Vertec, students should be pre-trained for vertical jump in order for the results to be more valid.

The fourth and eighth rows of the table contain data from a survey conducted on the student population. In the first work 20 subjects, in the second 89. Both researches were done with the Opto-jump device. The Opto-jump photocell system has shown strong competitive validity and excellent test-retest reliability for estimating vertical jump height. Also in the paper [24], with the aim of determining the connection between the explosive power of the legs and the running speed, the Opto-jump instrument found extraordinary application in research.

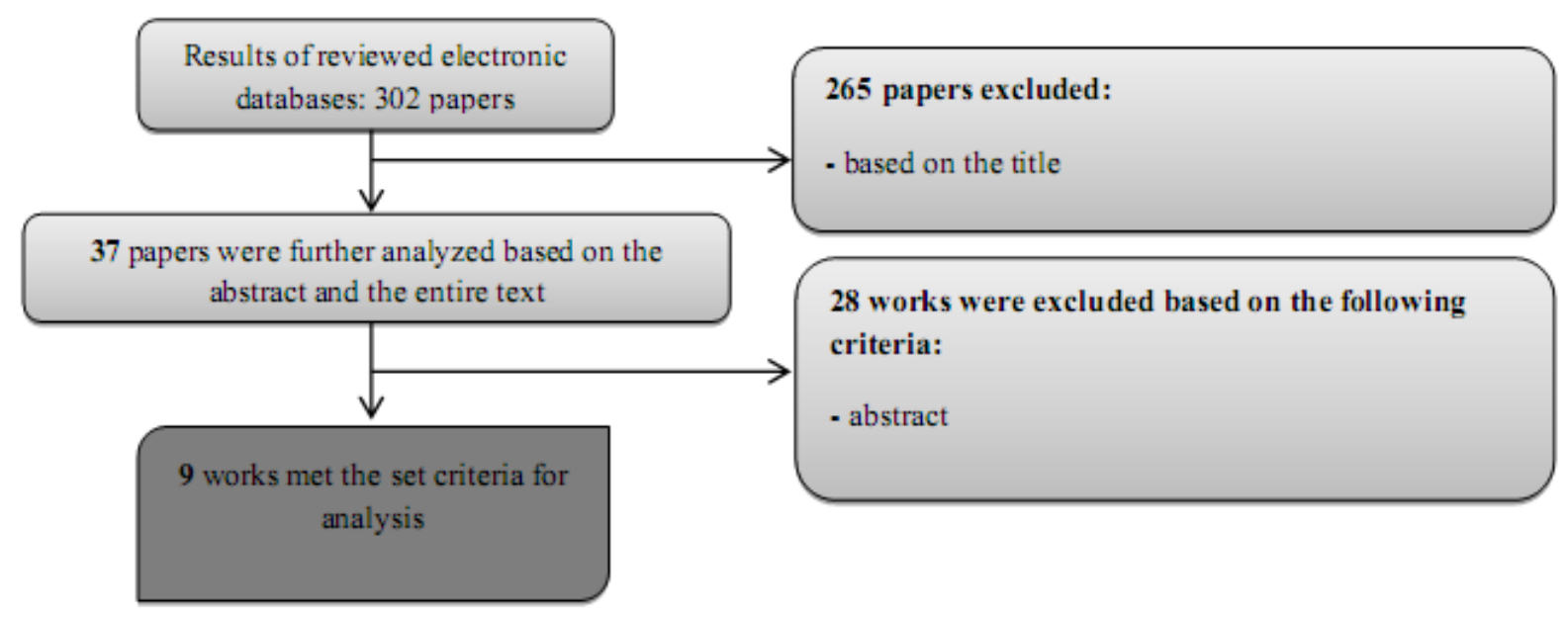

Figure 1 The process of collecting, analyzing and eliminating found works. 
Table 1 Shows nine original scientific papers in the period from 2009 to 2014 . The number of respondents included in this research is 400 .

\begin{tabular}{|c|c|c|c|c|}
\hline References & Population & Grouping & $\begin{array}{c}\text { Instrumentation and } \\
\text { treatment }\end{array}$ & Results \\
\hline $\begin{array}{l}\text { [19] Bosquet, } \\
\text { Berryman, \& } \\
\text { Dupuy (2009) }\end{array}$ & $\begin{array}{c}\text { Male and female } \\
\text { student } \\
\text { population }\end{array}$ & $\begin{array}{l}n=73 \text { subjects } \\
(40 w, 33 \mathrm{~m}) .\end{array}$ & $\begin{array}{l}\text { OJ (Microgate, Italy); IR-mat, } \\
\text { GES, Sweden. Flight time, } \\
\text { contact time, jump time. }\end{array}$ & $\begin{array}{l}\text { Opto-jump provides higher } \\
\text { values. We concluded that } \\
\text { both systems could be } \\
\text { used alternately, with } \\
\text { relatively small differences. }\end{array}$ \\
\hline $\begin{array}{l}\text { [20] Bubanj } \\
\text { et al., (2010) }\end{array}$ & $\begin{array}{l}\text { Male student } \\
\text { population }\end{array}$ & $\begin{aligned} \mathrm{n}= & 10 \text { subjects } \\
& (10 \mathrm{~m}) .\end{aligned}$ & $\begin{array}{l}\text { MT (SA, Sion, Switzerland). The } \\
\text { task consisted of performing } \\
\text { five vertical jumps. }\end{array}$ & $\begin{array}{l}\text { The Myotest is reliable and } \\
\text { easy to operate. It can be } \\
\text { used for various protocols. }\end{array}$ \\
\hline $\begin{array}{c}\text { [18] Nuzzo, } \\
\text { Anning, \& } \\
\text { Scharfenberg } \\
(2011) \\
\end{array}$ & $\begin{array}{c}\text { Male and female } \\
\text { student } \\
\text { population }\end{array}$ & $\begin{array}{l}n=79 \text { subjects } \\
(39 w, 40 \mathrm{~m}) .\end{array}$ & $\begin{array}{l}\text { MT, Jyst Jump; Vertec. Vertical } \\
\text { jump (3 types of effort). }\end{array}$ & $\begin{array}{c}\text { The most valid results } \\
\text { were obtained using } \\
\text { Myotest, using Vertec } \\
\text { observed errors. } \\
\end{array}$ \\
\hline $\begin{array}{l}\text { [21] Glatthorn } \\
\text { et al. (2011) }\end{array}$ & $\begin{array}{l}\text { Male student } \\
\text { population }\end{array}$ & $\begin{aligned} \mathrm{n}= & 20 \text { subjects } \\
& (20 \mathrm{~m}) .\end{aligned}$ & $\begin{array}{l}\text { OJ (Microgate, Italy). Vertical } \\
\text { jump (maximum squat) }\end{array}$ & $\begin{array}{l}\text { Opto-jump with cells is a } \\
\text { valid and reliable tool for } \\
\text { estimating the height of a } \\
\text { vertical jump. }\end{array}$ \\
\hline $\begin{array}{c}\text { [22] Herodek, } \\
\text { Živković, } \\
\text { Petković, } \\
\text { Veličković, \& } \\
\text { Aleksic (2011) } \\
\end{array}$ & $\begin{array}{l}\text { Competitors in } \\
\text { gymnastics }\end{array}$ & $\begin{aligned} \mathrm{n}= & 10 \text { subjects } \\
& (10 \mathrm{w}) .\end{aligned}$ & $\begin{array}{l}\text { MT (SA, Sion, Switzerland). } \\
\text { Height, power, force, velocity. } \\
\text { Explosive leg warm-up } \\
\text { protocol. }\end{array}$ & $\begin{array}{l}\text { Static stretching significant } \\
\text { results; dynamic stretching } \\
\text { significant results; ballet } \\
\text { preparation insignificant } \\
\text { results. }\end{array}$ \\
\hline $\begin{array}{c}\text { [11] Markovic } \\
\text { \& Herodek } \\
\text { (2011) }\end{array}$ & $\begin{array}{l}\text { A sample of } \\
\text { handball and } \\
\text { volleyball } \\
\text { players }\end{array}$ & $\begin{array}{c}\mathrm{n}=30 \\
\text { respondents (6 } \\
\text { handball } \\
\text { players, } 24 \\
\text { volleyball } \\
\text { players). }\end{array}$ & $\begin{array}{l}\text { MT (Sion, Switzerland), GES } \\
\text { (Globus, Codogne, Italy). Six } \\
\text { VS with as little lower leg } \\
\text { flexion as possible. }\end{array}$ & $\begin{array}{l}\text { There was a difference of } \\
9 \% \text { in favor of Myotest. } \\
\text { This test is an effective } \\
\text { tool for assessing VS. }\end{array}$ \\
\hline $\begin{array}{l}\text { [23] Castagna } \\
\text { et al., (2013) }\end{array}$ & Rugby players & $\begin{aligned} \mathrm{n}= & 20 \text { subjects } \\
& (20 \mathrm{~m}) .\end{aligned}$ & $\begin{array}{l}\text { OJ \& MT. } 86 \text { rebounds, field } \\
\text { conditions, VS. }\end{array}$ & $\begin{array}{l}\text { The difference between } \\
\text { these two systems is } \\
\text { significant. Myotest time is } \\
7.2 \% \text { longer than with } \\
\text { Opto-jump. Both systems } \\
\text { are valid. }\end{array}$ \\
\hline $\begin{array}{c}\text { [24] } \\
\text { Milosevic, } \\
\text { Kreft, \& } \\
\text { Mucibabic } \\
(2014) \\
\end{array}$ & $\begin{array}{l}\text { Male and female } \\
\text { student } \\
\text { population, } 21.44 \\
\quad \pm 1.6\end{array}$ & $\begin{array}{l}n=89 \text { subjects } \\
(30 \mathrm{w}, 59 \mathrm{~m}) .\end{array}$ & $\begin{array}{l}\text { VS (OJ), velocity estimation } \\
\text { test (photocells). }\end{array}$ & $\begin{array}{l}\text { Static correlation of tested } \\
\text { variables. ES code } \\
\text { DE affects running speed. }\end{array}$ \\
\hline $\begin{array}{l}\text { [25] Santos, } \\
\text { Gascon, } \\
\text { Lopez, \& } \\
\text { Garatachea } \\
\text { (2014) }\end{array}$ & $\begin{array}{l}\text { Volunteer } \\
\text { participants }\end{array}$ & $\begin{array}{c}n=28 \text { subjects, } \\
18-28 \text { gs. }\end{array}$ & $\begin{array}{c}\text { GES \& OJ. Maximum jump 90o, } \\
\text { MS with free flexion, CMJ, } \\
\text { Abalak jump. }\end{array}$ & $\begin{array}{l}\text { Opto-Jump gives less value } \\
\text { compared to Globus Ergo } \\
\text { Tester. These systems give } \\
\text { different results. }\end{array}$ \\
\hline
\end{tabular}


The fifth row of the table contains data from a survey conducted on a sample of 10 female gymnasts. The research was conducted with the aim of determining the effect of different warm-up protocols on the results of tests measuring the explosive power of the legs that were assessed by Myotest during the performance of the high jump from the place. Static stretching gave significant results, dynamic stretching gave significant results, ballet preparation had insignificant results.

In the sixth work of the table, a double instrumentation was used. Myotest and Ergojump. The sample consisted of 6 handball players and 24 volleyball players. The testing protocol was based on performing six jumps with as little knee flexion as possible. There was a difference of $9 \%$ in favor of Myotest. This test is an effective tool for estimating vertical jumps.

The seventh paper of the table contains research data on a sample of rugby players. The number of respondents in the paper is 20. Using Optojump and Myotest, the jumps were monitored and thus tests of athletes were performed. The difference between these two systems is significant. Myotest time is $7.2 \%$ longer than with Opto-jump. Both systems are valid and can be used.

In the last work of the table, the respondents were voluntary participants, ie. 28 respondents. Globus Ergo Tester and Opto-Jump were used as instruments. Based on the tested tests, Opto-Jump gives lower values compared to the Globus Ergo Tester. These systems give different results but both are valid for use.

\section{Conclusion}

In the last fifteen years, the instrumentation has been increasingly used, both in laboratory conditions and in the field, for various measurements in both recreational and professional sports. A review of the relevant literature concludes that there are certain differences when comparing the results for each of the instruments. However, the high price is only one of the segments that affects the possibility of using the above. Myotest has stood out as the smallest instrument and is easily portable and therefore effective to use. The assessment of explosive power is easy to perform, and the results it gives are reliable.

\section{References}

[1] A.J. Blazevich, \& N.D. Gill, Reliability of unfamiliar, multijoint, uniand bilateral strength tests: Effects of load and laterality, Journal of Strength \& Conditioning Research, 20 (2006) 226-230. [DOI] I [PubMed]

[2] A.J. Bruenger, S.L. Smith, W.A. Sands, \& M.R. Leigh, Validation of instrumentation to monitor dynamic performance of Olympic weightlifters, Journal of Strength \& Conditioning Research, 21 (2007) 492-499. [DOI] I [PubMed]

[3] K. Sato, S.L. Smith, \& W.A. Sands, Validation of an accelerometer for measuring sport performance. Journal of Strength \& Conditioning Research, 23 (2009) 341-347. [DOI] | [PubMed]

[4] P. Cormie, R. Deane, \& J.M. McBride, Methodological concerns for determining power output in the jump squat, Journal of Strength \& Conditioning Research, 21(1) (2007) 424-430. [DOI] | [PubMed]

[5] H.C. De Vet, C.B. Terwee, L.B. Mokkink, \& D.L. Knol, (2011) Measurement in medicine: A practical guide. New York, Cambridge University Press.978-0-521-11820-0

[6] W. Dessalegn, \& K.A. Alemmebrat, The Effect Of Explosive Power, Flexibility And Speed Training On Long Jump Performance: The Case Of Burayu Town Athletics Club, International Journal of Health, Physical Education and Computer Science in Sports, 36 (2020) 71-80.

[7] Bubanj, R., \& Brankovic, M. (1997). Athleticstechniques and methodics. Nis: Authors.

[8] M.D. Peterson, D.J. Dodd, B.A. Alvar, M.R. Rhea, \& M. Favre, Undulation training for development of hierarchical fitness and improved firefighter job performance, Journal of Strength \& Conditioning Research, 22 (2008) 1683-1695. [DOI] । [PubMed]

[9] B. Jidovtseff, J.M. Crielaard, S. Cauchy, \& J.L. Croisier, Validity and reliability of an inertial dynamometer using accelerometry (Validité et reproductibilité d'un dynamometer inertiel basé surl'accélérométrie. In French.). Science \& Sports, 23 (2008) 94-97. [DOI]

[10] A. Struzik, J. Zawadzki, A. Rokita, \& P. Pietraszewski, Application of an Accelerometric System for Determination of Stiffness during a 
Hopping Task, Applied Bionics and Biomechanics, 24(11) (2020) 3186-3193. [DOI]

[11] K. Markovic, \& K. Herodek, Measuring explosive leg strength using myotest. Sport Mont, 31, 32, 33(9) (2011) 81-83.

[12] J.R. Hoffman, \& J. Kang, Evaluation of a new anaerobic power testing system, Journal of Strength \& Conditioning Research, 16(1) (2002) 142-148. [PubMed]

[13] B. Kenny, \& C. Gregory, (2006). Volleyball/steps to success. Champain, IL Human Kinetics.

[14] C. Bosco, \& P. Luhtanen, P.V. Komi, A simple method for measuring mechanical power in jumping, European Journal of Applied Physiology and Occupational Physiology, 50(2) (1983) 273282. [DOI] | [PubMed]

[15] P.V. Komi, \& C. Bosco, Utilization of stored elastic enery in leg extensor muscles by men and women, Medicine \& Science in Sports \& Exercise, 10 (1978) 261-265. [PubMed]

[16] A. Attia, W. Dhahbi, A. Chaouachi, J. Padulo, D.P. Wong, \& K. Chamari, Measurement errors when estimating the vertical jump heightwith flight time using photocell devices: the example of Optojump, Biology of Sport. 34(1) (2017) 63-70. [DOI] I [PubMed]

[17] G. Moir, P. Shastri, \& C. Connaboy, Intersession reliability of vertical jump height in women and men, Journal of Strength \& Conditioning Research, 22(6) (2008) 1779-1784. [DOI] । [PubMed]

[18] J.L. Nuzzo, J.H. Anning, \& J.M. Scharfenberg, The Reliability of Three Devices Used for Measuring Vertical Jump Height, Journal of Strength \& Conditioning Research, 25(9) (2011) 2580-2590. [DOI] | [PubMed]

[19] L. Bosquet, N. Berryman, \& O. Dupuy, A Comparison of 2 Optical Timing Systems Designed to Measure Flight Time and Contact Time During Jumping and Hopping, Journal of Strength \& Conditioning Research, 23(9) (2009) 2660-2665. [DOI] | [PubMed]

[20] S. Bubanj, R. Stankovic, R. Bubanj, I. Bojic, B. Djindjic, \& A. Dimic, Reliability of myotest tested by a countermovement jump, Acta Kinesiologica, 4(2) (2010) 46-48.
[21] J.F. Glatthorn, S. Gouge, S. Nussbaumer, S. Stauffacher, F.M. Impellizzeri, \& N.A. Maffiuletti, Validity and Reliability of Optojump Photoelectric Cells for Estimating Vertical Jump Height, Journal of Strength \& Conditioning Research, 25(2) (2011) 556-560. [DOI] | [PubMed]

[22] K. Herodek, M. Zivkovic, E. Petkovic, S. Velickovic, \& A.V. Aleksic, The effects of different warm-up protocols on explosive leg strength in women sport gymnastics, Sport Mont, 31, 32, 33(9) (2011) 69-74.

[23] C. Castagna, M. Ganzetti, M. Ditroilo, M. Giovannelli, A. Rocchetti, \& V. Manzi, Concurrent Validity of Vertical Jump Performance Assessment Systems, Journal of Strength \& Conditioning Research, 27 (3) (2013) 761-768. [DOI] । [PubMed]

[24] N. Milošević, R. Kreft, \& M. Mučibabić, (2014). Relationship between explosive power test and running speed. Fourth International Conference, Proceedings. Sports sciences and health, Banja Luka 14.03.2014.

[25] A.L. Santos, R. Gascon, I. Lopez, \& N. Garatachea, Comparison Of Two Systems Designed To Measure Vertical Jump Height. [Comparison of the two systems designed for medium vertical height], Revista internacional de ciencias del deporte, 10(36) (2014) 123-128. [DOI]

\section{Authors Contribution}

All the authors (BC, LM, MZ \& DB) contributed equally to the manuscript and have read and approved the manuscript (data acquisition, analysis, interpretation, manuscript drafting). Bojan Bjelica designed the work and finalized the manuscript.

\section{Conflict of interest}

The authors have no conflicts of interest to declare that they are relevant to the content of this article.

\section{Funding}

No funding was received to carry out this study

\section{About The License}

(c) The Author(s) 2021. The text of this article is open access and licensed under a Creative Commons Attribution 4.0 International License 